\title{
An empirical investigation to analysis the dimensions of cultural security: A case study of educational system
}

\author{
Elyas Nouraei $^{\mathrm{a}^{*}}$, Mohammad Safari Kahreh ${ }^{\mathrm{b}}$ and Zahra Safari Kahreh ${ }^{\mathrm{c}}$
}

\section{H R O N I C L E}

\section{Article history:} \\ Received October 12, 2012 \\ Received in revised format \\ 29 November 2012 \\ Accepted 28 December 2012 \\ Available online \\ January 42013 \\ Keywords: \\ Culture \\ Cultural security \\ Empirical study \\ Exploratory research \\ University
}

${ }^{a}$ Assistant Professor, Razi University of Kermanshah, Iran

${ }^{b} \mathrm{PhD}$ candidate of Strategic Management, University of Tehran, Tehran, Iran

${ }^{c} M S c$ in Managerial Finance and Lecture of Bakhtar University, Ilam, Iran

\begin{abstract}
A B S T R A C T
The purpose of this study is to explore the concept of cultural security and its practical implications in a case study of educational system. There are several definitions of culture, which describe different aspects of cultural security. In fact, cultural security tends to show various behaviors, thinking, beliefs and other people's perspectives in a society, which represents the overall circumstances. Cultural security and its issues make it possible to have a clear image of a society or community. This paper aims to identify the important dimensions of cultural security in terms of basic components of cultural security identified in a framework. Therefore, after identifying the components, using a questionnaire, required data are gathered from the universities of the city of Ilam, Iran and they are analyzed by SPSS18.0 software and its appropriate statistical tests.
\end{abstract}

\section{Introduction}

Developing a greater understanding of cultural issues especially cultural security in the university context due to its complexity and applicability is important area of research. Cultural security tends to show many of behaviors, thinking, beliefs and other aspects of people in a society that represent the overall its space and circumstances. Based on cultural security and its issues, it is possible to have a clear image of a society or community. Zhu (2008) used cultural security to describe shared community-especially university context-value, which influence member's attitudes and behaviors and reported that cultural values hold great control on people's social behaviors. Despite the recent interest in safety culture, there is still considerable disagreement and confusion about what safety culture really is (Antonsen, 2009; Nazemi et al., 2012; Nemati, 2012). Conceptualizing the dimensions of cultural security is the primary purpose of this research and the basic research question is to know the main components or the cultural security in the university context.

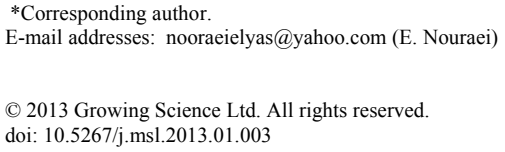




\section{Literature Review}

\subsection{Culture}

Culture incorporates of various components including patterns, explicit and implicit behavior acquired and transmitted by symbols including the distinctive achievement of human groups, including their embodiments in artifacts. The essential core of culture includes traditional ideas and their associated values. On one hand, cultural systems may be considered as products of action as conditioning impacts on further action. Table 1 shows the main definitions of culture, which highlights the basic aspects of this concept.

\section{Table 1}

Basic definitions of culture

No. Basic definitions of Culture

- Culture is associated with the cumulative deposit of knowledge, experience, beliefs, values, meanings, attitudes, hierarchies, religion, notions of time, roles, spatial relations, concepts of the universe, and material objects and possessions acquired by a group of people in the course of generations through individual and group striving.

2 - Culture is the systems of knowledge shared by a large group of people.

3 - Culture is communication and communication is culture.

- Culture in its broadest sense is cultivated behavior; which is the totality of a person's

4 learned, accumulated experience socially transmitted, or more briefly, behavior through social learning.

- A culture is a method of life of a group of people' behaviors, beliefs, values, and symbols

5 that they accept, generally without thinking about them, and that are passed along by communication and imitation from one generation to another.

- Culture is a kind of symbolic communication and some of its symbols incorporate a

6 group's skills, knowledge, attitudes, values, and motives. The meanings of the symbols are learned and intentionally perpetuated in a society through its institutions.

- Culture includes different patterns, explicit and implicit, of and for behavior acquired and transmitted by symbols, constituting the distinctive achievement of human groups, including their embodiments in artifacts.

- Culture is the sum of total of the learned behavior of a group of people, which are often considered to be people' customs and are transmitted from generation to generation.

- Culture is a collective programming of the mind, which distinguishes the members of one group or category of people from another.

Cultural differences manifest themselves in various directions and differing levels of depth. Symbols are the most superficial and value the deepest manifestations of culture, with heroes and rituals in between.

- Symbols are words, gestures, pictures, or objects that carry a specific meaning, which is only recognized by those who share a specific culture. As new symbols easily develop, old ones steadily disappear, others often adopt symbols from one specific group, and this is why symbols represent the outermost layer of a culture.

- Heroes are people, past or present, real or fictitious, who possess characteristics, which are highly prized in a culture and serve as models for desirable behavior.

- Rituals are sets of essential activities, superfluous in reaching expected objectives carried out for people's own sake.

- Values forms the core component of a culture and they are broad tendencies for preferences of certain state of affairs to others in terms of good-evil or right-wrong, etc. Many values keep 
unconscious to those who hold them and they often are not investigated or other people observe them, directly.

Heroes, symbols as well as rituals are the tangible or visual aspects of the practices of a culture. However, the true cultural meaning of the practices is intangible, which is disclosed only when the practices are interpreted by the insiders.

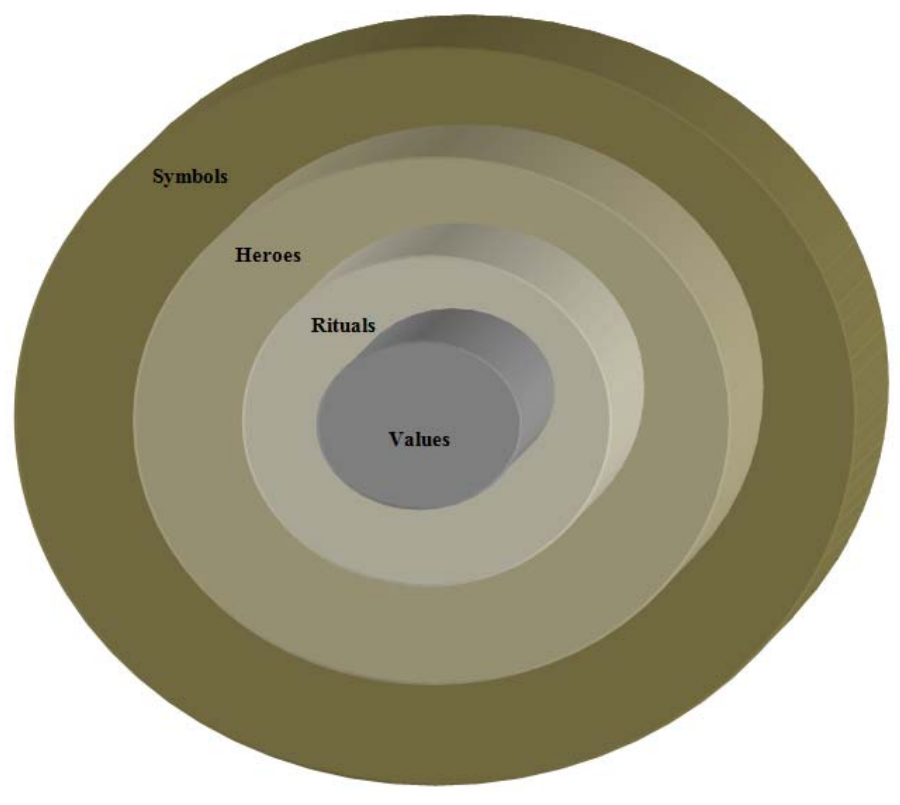

Fig. 1. Manifestation of culture at different levels of depth

\subsection{Categorization of culture}

According to Hammerly (1982), a tripartite categorization of culture includes achievement culture, informational culture, and behavioral culture. Achievement culture is associated with the great achievement of a society while informational culture is devoted to the valued information describing a society, such as history, the valued information, and other perspectives of a society. The third one, behavioral culture, is associated with the common behaviors where culture dictates individuals' exhibit in the society. This type of behavior incorporates daily greeting, giving compliments, communicative eye contact, etc. (Zhu, 2008). Hammerly's framework explains how a culture presents itself and three aspects of culture in Hammerly's framework, achievement, information, and behavior, are three accesses where people ought to learn about a culture (Zhu, 2008).

However, the primary assumption is the essence of a culture since this is the key components for understanding the nature of people, and people's relationships with others. Therefore, basic assumptions and values also influence people's behaviors and beliefs towards others (Zhu, 2008).

Every culture incorporates a series of key beliefs and concepts, which are described as the cultural values where people share in a specific culture. Cultural values include the core of the culture layers because cultural values penetrate other dimensions of culture and have dominated power on them. Hofstede's (1991) discussed cultural values and recognized the dominance of cultural values over behaviors, and claimed that cultural values inform and maintain particular norms of interaction and interpretation reflected in the communicative behaviors of individuals. Cultural values have cognitive, affective, and behavioral components (Mooij, 2004), in specific circumstances that cultural values influence the way people think, feel and act.

Cultural themes are associated with the behavioral perspective of cultural values. The working concept of cultural themes in this study is described as the behavioral norms shared among members 
of a society in their pursuit of specific cultural values. There are two essential components in a cultural theme including a behavioral pattern shared in the society and the cultural value underlying that behavioral pattern ( $\mathrm{Zhu}, 2008)$.

\subsection{Cultural security}

One of the requirements in the human life is the necessity for security, which is the primary expectation of people from their government and states. Impacts of security on the main aspects of society such as economics, culture, industry etc. bring peace of mind. Cultural security is something in the accepted public values, security in the history and civilization such as security script, and language and cultural heritage against cultural invasion. In this context, the security issue has been involved with the cultural concepts. If we observe the culture in three basic components including knowledge, beliefs and behavior, then the set of these three components will happen in the foster of a generation in the society, which mainly demonstrate in the framework of educational system. Therefore, cultural security includes different items and it can best describe the situations of the university as an important role in the achievements of the society especially university.

\section{Research conceptual framework}

The present study introduces a comprehensive framework for cultural security in the university context, after literature review using experts and professional's feedbacks and a detailed framework for cultural security is determined. This framework contains 20 basic components, which represent the primary aspects of the cultural security in the university context. By using this framework, various dimensions of cultural security in terms of students' viewpoints are surveyed. Components are encompasses scientific, non-scientific and religious elements that best represent the cultural circumstances in the university context. Table 2 shows this framework in detail.

\section{Table 2}

Identified components of the cultural security in the university

\begin{tabular}{|c|c|c|c|}
\hline No. & Components & No. & Components \\
\hline 1 & Level of science quality in the university & 11 & $\begin{array}{l}\text { Promoting the element of Iranian-Islamic culture in } \\
\text { the university }\end{array}$ \\
\hline 2 & Level of science quantity in the university & 12 & Student's beliefs and credence \\
\hline 3 & Attentions to the art and its upgrade & 13 & Attention of students toward the art \\
\hline 4 & Student's ethics and it's growth & 14 & Social ethics of students \\
\hline 5 & Acceptation of conventional roles of universities & 15 & Political ethics of students \\
\hline 6 & Customs of university in serve to progress & 16 & Degree of study among youth in the society \\
\hline 7 & Worship and rituals & 17 & Cultural freedom via universities culture \\
\hline 8 & Attention to the last poets & 18 & $\begin{array}{l}\text { Trust towards the university officials endeavors about } \\
\text { the culture affairs }\end{array}$ \\
\hline 9 & $\begin{array}{l}\text { Contemporary poets in the context of navel Iranian } \\
\text { culture }\end{array}$ & 19 & $\begin{array}{l}\text { Beliefs of students to have a superior culture among } \\
\text { all of the world }\end{array}$ \\
\hline 10 & $\begin{array}{l}\text { Efforts of those involved in order to promotion of } \\
\text { university culture }\end{array}$ & 20 & Valuable cultural mix of Islam and Iran \\
\hline
\end{tabular}

\section{Methodology}

\subsection{Research method}

This is an applied-developmental research and the research based on information collection method, it is classified as a descriptive one. Descriptive study is a set of techniques to describe studied circumstances or phenomena. Descriptive study is implemented to understand current circumstances better and help in decision making process. For doing this study, cross-sectional survey is applied to explain research basic components. The study explains the relationships among them and constructs the research conceptual framework. 


\subsection{Statistical population and sample}

The study consists of 110 students from one of the universities in the Ilam province located in south part of Iran who participated in the survey.

\subsection{Data collection}

The basic tool for data gathering in this research was questionnaire. In addition, the most important methods of collecting data in this study are as below:

1) Documentary studies: document sources, articles, required books and internet was used in this part in order to collect information about theoretical base and research literature and to identify the basic components of the cultural security in the university and constructing the research conceptual framework.

2) Field Studies: in this part in order to collect data and information in order to analyze and test the basic research conceptual framework, questionnaires were used.

Also for data analysis the SPSS18.0 and LISREL8.7 software were used and according to software basic and related statistical tests were defined and then were run.

\subsection{Validity and reliability}

Validity and reliability are two necessary features for every measuring material such as questionnaire because these materials should analyze data and provide conclusions for researchers.

\subsubsection{Validity}

To sum up, validity means that a measuring material is used to measure the characteristics. In this research to confirm the validity of the research's questionnaire, the Factor Analysis was implemented. For questionnaire of this research, there were 37 questions that after factor analysis, common amounts of all items were above the 0.5 and remained in the analysis. Table 1 will show the KMO of Sampling Adequacy for this research, Sig and Bartlett's Test of Sphericity, which all demonstrated that research is so appropriate and valid.

\section{Table 3}

Results of factor analysis test for validity of the research

\begin{tabular}{ll}
\hline Statistic of the Test & Items of questionnaire \\
\hline KMO of Sampling Adequacy & 0.786 \\
Bartlett's Test of Sphericity & 1270.710 \\
Df & 666 \\
Sig & 0.000 \\
\hline
\end{tabular}

\subsubsection{Reliability}

To meet the reliability confirmation in this research, the Cronbach's alpha (Cronbach, 1951) was calculated. A questionnaire consist of 37 questions was used for data collection. Questions were evaluated by the Likert 5-choice measurement. Cronbach's alpha Coefficient was used to measure reliability.

The average of Cronbach's alpha for big factors and other sub-factors of this research were 0.814 that is more than the mean acceptable alpha and is very high amount for this test. Hence, the questionnaire is completely reliable. Reliability of the questions was evaluated. Table 3 shows the results (Alpha Cronbach is used to test the reliability of the materials used in the research). All these parts bear high reliability $(\alpha>0.7)$. 
Table 4

Reliability test results

\begin{tabular}{|c|c|c|c|}
\hline \multicolumn{4}{|c|}{ Case Processing Summary } \\
\hline & & $\mathrm{N}$ & $\%$ \\
\hline \multirow[t]{3}{*}{ Cases } & Valid & 110 & 100.0 \\
\hline & Excluded $^{\mathrm{a}}$ & 0 & 0.0 \\
\hline & Total & 110 & 100.0 \\
\hline \multicolumn{4}{|c|}{ Reliability Statistics } \\
\hline \multicolumn{3}{|c|}{ Cronbach's Alpha } & $\mathrm{N}$ of Items \\
\hline \multicolumn{3}{|c|}{0.814} & 37 \\
\hline
\end{tabular}

\section{Analysis}

In this section of paper, using SPSS18.0 software, appropriate and related tests have been used. To measure the affectability of each of the cultural security components, one sample t-test has been used. This statistical test demonstrates the significant effects of each of the components on the independent variable that is cultural security.

\subsection{Descriptive statistics of this research}

For data gathering, the university students have been participated in the survey. In this section of the paper results of the analysis of related descriptive statistics have been presented. Table 5 and 6 show the results analysis for the two variables including Gender and Age.

Table 5

Results of analysis for "Gender" variable in this research

\begin{tabular}{cccccc}
\hline \multirow{5}{*}{ Valid } & \multicolumn{5}{c}{ Variable: Gender } \\
& Male & 58 & 52.7 & 52.7 & Cumulative Percent \\
\cline { 2 - 6 } & Female & 52 & 47.3 & 47.3 & 52.7 \\
& Total & 110 & 100.0 & 100.0 & 100.0 \\
\hline
\end{tabular}

\section{Table 6}

Results of analysis for "Age" variable in this research

\begin{tabular}{ccccc}
\hline Valid & Frequency & Percent & Valid Percent & Cumulative Percent \\
\hline$<20$ & 37 & 33.6 & 33.6 & 33.6 \\
$20-22$ & 39 & 35.5 & 35.5 & 69.1 \\
$22-24$ & 20 & 18.2 & 18.2 & 87.3 \\
$24-26$ & 11 & 10.0 & 10.0 & 97.3 \\
$26-28$ and upper & 3 & 2.7 & 2.7 & 100.0 \\
Total & 110 & 100.0 & 100.0 & \\
\hline
\end{tabular}

\subsection{Testing affectability of the identified components of the cultural security in the university}

In this section of the paper in order to test the affectability of the all identified components -including 20 basic components- the one sample t-test has been used. Table 7 shows the results of this test. 
Table 7

Results of "One-Sample Statistics" of t-test for all 20 components

\begin{tabular}{|c|c|c|c|c|}
\hline Components & $\mathrm{N}$ & Mean & $\begin{array}{c}\text { Std. } \\
\text { Deviation }\end{array}$ & $\begin{array}{l}\text { Std. Error } \\
\text { Mean }\end{array}$ \\
\hline Level of science quality in the university & 110 & 4.2000 & 1.24738 & .11893 \\
\hline Level of science quantity in the university & 110 & 3.9273 & 1.13096 & .10783 \\
\hline Attentions to the art and its upgrade & 110 & 4.5780 & 1.09116 & .10451 \\
\hline Student's ethics and it's growth & 110 & 4.6545 & 3.18090 & .30329 \\
\hline Acceptation of conventional roles of universities & 110 & 4.5727 & 2.98454 & .28457 \\
\hline Customs of university in serve to progress & 110 & 4.7364 & 1.14681 & .10934 \\
\hline Worship and rituals & 110 & 4.9091 & 1.17735 & .11226 \\
\hline Attention to the last poets & 110 & 4.6881 & 1.30311 & .12482 \\
\hline Contemporary poets in the context of navel Iranian culture & 110 & 5.0545 & 2.16662 & .20658 \\
\hline $\begin{array}{l}\text { Efforts of those involved in order to promotion of university } \\
\text { culture }\end{array}$ & 110 & 4.6182 & 1.24872 & .11906 \\
\hline Promoting the element of Iranian-Islamic culture in the university & 110 & 5.0642 & 1.02988 & .09864 \\
\hline Student's beliefs and credence & 110 & 4.3727 & 3.12392 & .29785 \\
\hline Attention of students toward the art & 110 & 4.2000 & 1.18709 & .11318 \\
\hline Social ethics of students & 110 & 4.7909 & 1.12597 & .10736 \\
\hline Political ethics of students & 110 & 4.6182 & 1.12504 & .10727 \\
\hline Degree of study among youth in the society & 110 & 4.7545 & 1.48501 & .14159 \\
\hline Cultural freedom via universities culture & 110 & 4.3727 & 1.12404 & .10717 \\
\hline $\begin{array}{l}\text { Trust towards the university officials endeavors about the culture } \\
\text { affairs }\end{array}$ & 110 & 4.7818 & 1.06987 & .10201 \\
\hline $\begin{array}{l}\text { Beliefs of students to have a superior culture among all of the } \\
\text { world }\end{array}$ & 110 & 4.4000 & 1.14299 & .10898 \\
\hline Valuable cultural mix of Islam and Iran & 110 & 4.3636 & 2.08853 & .19913 \\
\hline
\end{tabular}

\section{Table 8}

Results of "One-Sample Test" of t-test for all 20 components

\begin{tabular}{|c|c|c|c|c|c|c|}
\hline \multicolumn{7}{|c|}{ Test Value $=3$} \\
\hline \multirow[t]{2}{*}{ Components } & \multirow[t]{2}{*}{$\mathrm{t}$} & \multirow[t]{2}{*}{ df } & \multirow{2}{*}{$\begin{array}{c}\text { Sig. } \\
\text { (2-tailed) }\end{array}$} & \multirow{2}{*}{$\begin{array}{c}\text { Mean } \\
\text { Difference }\end{array}$} & \multicolumn{2}{|c|}{$\begin{array}{l}95 \% \text { Confidence Interval } \\
\text { of the Difference }\end{array}$} \\
\hline & & & & & Lower & Upper \\
\hline Level of science quality in the university & 1.682 & 109 & .006 & .20000 & .0357 & .4357 \\
\hline Level of science quantity in the university & .674 & 109 & .001 & .07273 & .2864 & .1410 \\
\hline Attentions to the art and its upgrade & 5.530 & 109 & .000 & .57798 & .3708 & .7851 \\
\hline Student's ethics and it's growth & 2.158 & 109 & .003 & .65455 & .0534 & 1.2556 \\
\hline Acceptation of conventional roles of universities & 2.013 & 109 & .007 & .57273 & .0087 & 1.1367 \\
\hline Customs of university in serve to progress & 2.411 & 109 & .008 & .26364 & .4804 & .0469 \\
\hline Worship and rituals & .810 & 109 & .002 & -.09091 & .3134 & .1316 \\
\hline Attention to the last poets & 2.499 & 109 & .004 & -.31193 & .5593 & .0645 \\
\hline $\begin{array}{l}\text { Contemporary poets in the context of navel Iranian } \\
\text { culture }\end{array}$ & .264 & 109 & .002 & .05455 & .3549 & .4640 \\
\hline $\begin{array}{l}\text { Efforts of those involved in order to promotion of } \\
\text { university culture }\end{array}$ & 5.192 & 109 & .000 & .61818 & .3822 & .8542 \\
\hline $\begin{array}{l}\text { Promoting the element of Iranian-Islamic culture } \\
\text { in the university }\end{array}$ & .651 & 109 & .006 & .06422 & .1313 & .2598 \\
\hline Student's beliefs and credence & 1.251 & 109 & .013 & .37273 & .2176 & .9631 \\
\hline Attention of students toward the art & 1.767 & 109 & .004 & .20000 & .0243 & .4243 \\
\hline Social ethics of students & 1.948 & 109 & .004 & .20909 & .4219 & .0037 \\
\hline Political ethics of students & 3.559 & 109 & .001 & .38182 & .5944 & .1692 \\
\hline Degree of study among youth in the society & 1.734 & 109 & .000 & .24545 & .5261 & .0352 \\
\hline Cultural freedom via universities culture & 5.853 & 109 & .000 & .62727 & .8397 & .4149 \\
\hline $\begin{array}{l}\text { Trust towards the university officials endeavors } \\
\text { about the culture affairs }\end{array}$ & 2.139 & 109 & .000 & .21818 & .4204 & .0160 \\
\hline $\begin{array}{l}\text { Beliefs of students to have a superior culture } \\
\text { among all of the world }\end{array}$ & 5.506 & 109 & .000 & .60000 & .8160 & .3840 \\
\hline Valuable cultural mix of Islam and Iran & 3.196 & 109 & .000 & .63636 & 1.0310 & .2417 \\
\hline
\end{tabular}


As we can observe from the results of Table 7 and Table 8, all 20 basic identified components of this research have influenced cultural security in the university context. Using the Mean and Sig. parameters, it is possible to conclude that these basic components of research positively have affected on the cultural security in the university and these components are meaningful in the university context.

\section{Conclusion}

This paper aimed to identify the most important dimensions of cultural security in terms of basic components of cultural security identified in a framework. Cultural security tends to show many of behaviors, thinking, beliefs and other aspects of people in a society that represent the overall its space and circumstances. Using cultural security and its issues make it possible to have a clear image of a society or community. Indeed, we used cultural security to describe shared community-especially university context-values, which influence member's attitudes and behaviors. Cultural values hold great control on people's social behaviors. To achieve the basic research purpose, after identifying the components of cultural security in the university context, required data for analyzing and testing the components have been gathered from universities of Ilam province. Using a questionnaire, we have surveyed students and then we have validated filled gathered questionnaire. Finally, data analysis has been applied and we have identified 20 components for the cultural security. The results have confirmed all of these components as effective components of cultural security in the university context.

\section{References}

Antonsen, S. (2009). Safety culture and the issue of power. Safety Science, (47) 183-191.

Cooper, M. D. (2000). Toward a model of safety culture. Safety Science, (36) 111-136.

Cronbach, L. J. (1951). Coefficient alpha and the internal structure of tests. Psychometrika, 16(3), 297-334.

Hammerly, H. (1982). Synthesis in Second Language Teaching: An Introduction to Linguistics. Blaine, Wash: Second Language Publications.

Hofstede, G. (1991). Cultures and organizations: Software of the mind. Maidenhead, NY: McGrawHill.

Mooij, M. K. (2004). Consumer Behavior and Culture: Consequences for Global Marketing and Advertising. Thousand Oaks, CA: Sage Publications.

Nazemi, S., Rahimnia, F., Lagzian, M., \& Ghayour, S.M. (2012). Investigating cultural influences on investment process in stock exchange. Management Science Letters, 2(8), 3041-3048.

Nemati, E. (2012). Cultural management and government role. Management Science Letters, 2(5), 1717-1720.

Wimpenny, P., Gault, B., MacLennan, V., Boast-Bowen, L., \& Shepherd, P. (2005).Teaching and learning about culture: A European journey. Nurse Education Today, 2(5) 398-404.

Zhu, B. (2008). Chinese cultural values and Chinese language pedagogy. A Thesis Presented in Partial Fulfillment of the Requirements for the Degree Master of Arts in the Graduate School of the Ohio State University. 